\title{
Performance analysis of downdraft gasifier for agriwaste biomass materials
}

\author{
K. Sivakumar and N. Krishna Mohan \\ Dept. of Mechanical Engineering, Annamalai University, Annamalai Nagar, Chidambaram-608 002, Tamil Nadu, India \\ ksr_aufeat@yahoo.co.in
}

\begin{abstract}
In this study, combustible gas production from shell biomass materials such as coconut shell, groundnut shell and rice husk was experimentally investigated at $800^{\circ} \mathrm{C}$ using gasification technique by a downdraft gasifier. The combustible gases $\mathrm{H}_{2}, \mathrm{CO}, \mathrm{CH}_{4}, \mathrm{CO}_{2}$, and $\mathrm{N}_{2}$ were formed. The calorific value of the producer gas for various shell materials was found. The calorific value of coconut shell is $23.01 \%$ higher than ground nut shell and $45.45 \%$ higher than rice husk. Based on performance analysis, it is concluded that coconut shell is the best suitable fuel for gasifier compared to the other two biomass shell materials.
\end{abstract}

Keywords: Biomass, gasification, coconut shell, groundnut shell, rice husk, energy from waste.

Introduction

Biomass is recognized as one of the major potential sources for energy production. Biomass resources viz. forestry residues, energy crops, manufacturing food waste, coconut shell, bagasse from sugarcane processes and food processing residue all have been used for energy generation.

Biomass gasification, the complete conversion of biomass to a gaseous fuel by heating it with a gasification medium such as air, oxygen or steam is fast becoming the most promising process for electricity generation. Biomass gasification products have been demonstrated for the generation of electricity via boilers and steam turbines or internal combustion engines, Fired in gas turbines and even proven suitable for some types of fuel cell.

Combustible gases viz. $\mathrm{H}_{2}, \mathrm{CO}, \mathrm{CH}_{4}, \mathrm{CO}_{2}$, and $\mathrm{N}_{2}$ were formed in the reactor (Adnan Midilli et al., 2001) reported the cashew nut as biomass fuel).

Shell biomass materials maintains net calorific values between $6000 \mathrm{~K} . \mathrm{cal} / \mathrm{kg}$ and $3000 \mathrm{~K} . \mathrm{cal} / \mathrm{kg}$. This is almost half that of natural gas and fuel oil. This coupled with the low mass density of biomass means it has a low energy density compared to fossil fuels and therefore shell bio mass materials are suitable for small scale plants (Savitri Garivait \& Ulonwan Chaiyo, 2006). There are various biomass shell materials are available in tropical countries. Where in the following three bio mass materials which are commonly available and reliable were taken for performance analysis (Singh et al., 2006):

\section{Biomass fuels}

1) Coconut shell was used as the feedstock with size range $0.75-1.0 \mathrm{~mm}$. The proximate and ultimate analysis of biomass as follows: moisture $10.53 \%$,fixed carbon $13.10 \%$,volatile matter $57.96 \%$ and ash $18.4 \%$. The ultimate analysis was C $50.2 \%, \mathrm{H} 5.30 \%, \mathrm{~N} 0.0 \%$ and $\mathrm{O}$ $43.4 \%$.

2) Ground nut shell has great potential for commercial use. It is used as fuel filler in cattle feed, hard particleboard, cork substitute, activated carbon etc. The Proximate analysis reveals that moisture $8.76 \%$, fixed carbon $15.50 \%$, volatile matter 54.96 and Ash $20.3 \%$. The ultimate analysis shows that C $48.3 \%, \mathrm{H} 5.70 \%, \mathrm{~N} 0.8 \%$ and $\mathrm{O} 39.4 \%$.

3) Rice husk is recognized as an important source of energy, particularly in developing countries where it economies largely based on agriculture and forestry. Agriculture waste is one form of biomass which is readily available but is largely not utilized in energy recovery schemes. Rice husks are an agriculture waste produce as a by-product of the rice milling industry. The world wide annual production of rice husks is estimated to be about 100 million tones, $90 \%$ of which generated in developing countries. The proximate analysis and ultimate analysis of biomass as follows: moisture $7.9 \%$, volatile matter $59.5 \%$, fixed carbon $19.9 \%$ and ash $17.1 \%$. The ultimate analysis was C $38.9 \%, \mathrm{H} 5.1 \%, \mathrm{~N} 0.6 \%, \mathrm{O} 32.0 \%$ (Van der Drift et al., 2001).

\section{Experimental setup and procedure}

The prototype small-scale biomass gasifier system comprised an agri-waste feed hopper and feed auger, air blower, cyclonic gasifier, external cyclone, cooler/condenser and engine (Fig.1).

\section{Equipment}

The biomass gasification system developed within this project was a swirling flow gasifier. The concept of this entrained flow gasifier used air to entrain shell biomass in a turbulent vortex within the reactor, which incorporated two stages of separation to remove the char and ash produced in the process. The intense continuous 
reaction enabled gasification of high volumes of biomass in the compact reactor. tests. Limited and controlled amount of air for partial combustion enters through the air nozzles (Fig.2).

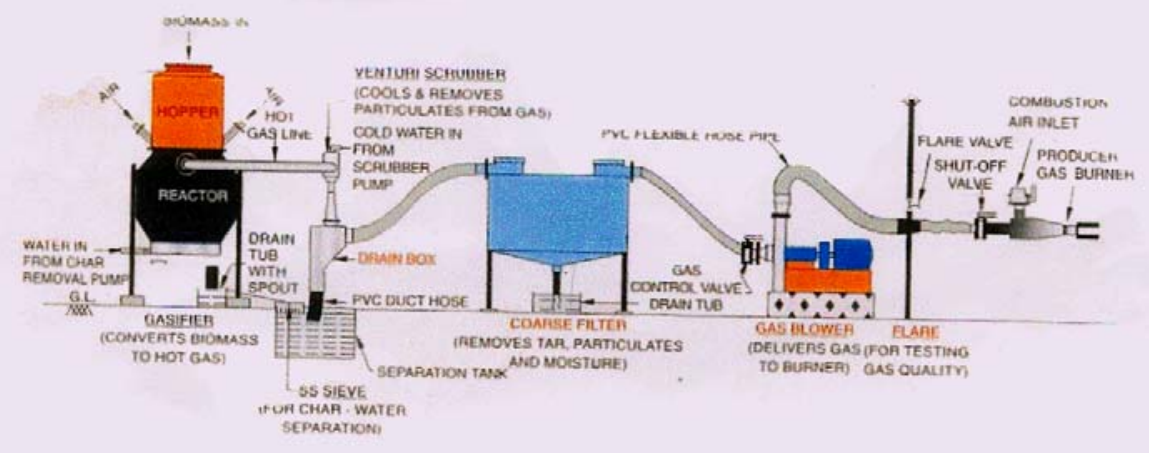

Fig. 1. Schematic diagram of biomass gasifier
The system used for this work was sized to gasify up to $20 \mathrm{~kg} / \mathrm{hr}$ of shell biomass under atmospheric pressure conditions; This gives a total energy input to the gasifier of around $20 \mathrm{~kW}$. The system was tested over a range fuel input rates from $12 \mathrm{~kg} / \mathrm{hr}$ up to $15 \mathrm{~kg} / \mathrm{hr}$. For the final testing with engine operation the gasifier was turned down to half its peak capacity of $20 \mathrm{~kg} / \mathrm{hr}$, results shown in this report reflect the performance of the gasifier in turn down operation (Philippe Mathieu \& Raphael Dubuisson, 2002). The final prototype gasifier was manufactured in 316-grade stainless steel and proved suitable when tested under continuous high temperature $800^{\circ} \mathrm{C}$ operation conditions. Khater et al. (1992) discussed behavior of downdraft gasifier and maximum temperature range, Pattaraporn Chaiprasert and Tharapong Vitidsant (2009) showed that increasing carbon conversion to gas from $44.13-78.43 \%$ where as tar was decreased from 19.55$1.4 \%$ at temperature of $800^{\circ} \mathrm{C}$.

\section{Heat-up gas burner}

A burner system was designed to supply and ignite a supplementary gas to fire through the gasifier to heat it up to temperatures to initiate gasification reaction. Specification temperatures were up to NOT for the reaction initiation. The design also ensured no interruption of the gasification reaction and not be fouled by biomass particles.

\section{Hopper/feeder system}

The biomass hopper and feed system have a small hopper with agitator provision. The hopper was small, however provided shell biomass loading of $15 \mathrm{~kg}$ of feedstock, which under most test conditions was suitable but needed refilling and agitation was required for longer rate for all bio mass.

\section{Cooler/condenser}

An array of ' $U$ ' tube design condensers were used to cool the Shell gas and condense any water and tars from the gas. The cooler was designed to reduce shell gas from temperatures of $700^{\circ} \mathrm{C}-800^{\circ} \mathrm{C}$ down to $30^{\circ} \mathrm{C}-40^{\circ} \mathrm{C}$, so that the maximum volumetric energy content of the shell gas is achieved. The design factored in minimum pressure drop across the system. Dogru et al. (2002) concluded that, the pressure drop is directly proportional to the air flow

\section{Filter}

The cool gas was filtered in various filter systems such as in fine filters and cloth bag filters to evaluate the performance of the upstream separation systems.

\section{Experimental procedure}

In the down draft gasifier, both the fuel and the gas flow downwards through the reactor enabling the pyrolysis gases to pass through a throated hot bed of char which is supported by a grate. This results in cracking of most of the tars in to non condensable gases and water. Furthermore, air is admitted to the fuel bed through air intake nozzles causing pyrolysis to charcoal and volatiles that partially burn as they are produced. The gaseous products of this flaming pyrolytic combustion then consume the charcoal produced during the pyrolysis and are reduced to fuel gas. In this way, tar vapors are typically lowered to $0.1 \%$ of the total feed. Whereas, in draft or cross flow gasifier, tar levels are higher than $0.1 \%$. Paulo R. Wander and Carlos (2004) reported the various level of tar gasification. Avdhesh and Sharma (2009) revealed the characteristic parameters of gasifier. This gas is used for operation of, internal combustion engine.

\section{Results and discussion}

The gasification experiments were performed for three agriwaste biomass materials. The volumetric flow rate of wet product gas was measured with a gas flow meter. Drying, pyrolysis and oxidation zone temperature of the gasifier and the water scrubber and box filter outlet temperature were also monitored with the aid of $\mathrm{R}$ and $\mathrm{K}$
Research article

Clndian Society for Education and Environment (iSee)
Biomass energy http://www.indjst.org
Sivakumar \& Krishna Mohan Indian J.Sci.Technol. 
type thermocouples. The amounts of tar-dust and condensate in the product gas were determined before and after cleaning the product gas. The combustible gases from the shell biomass were obtained as $\mathrm{H}_{2}, \mathrm{CO}$, $\mathrm{CO}_{2}, \mathrm{CH}_{4}$, and $\mathrm{N}_{2}$ and their amounts in the dry product gas were estimated in units of $\mathrm{kg} \mathrm{h}^{-1}$ and as volume by volume percentage.

The calorific value and total energy of the produced gases were determined and evaluated based on the dry product gas volumetric flow at STP hot cold and raw gas efficiencies of the dry product gas were estimated in order to investigate its usage in the CHP engines. During the experiment, pressure drops were measured as $0.10-0.80$ $\mathrm{mm} \mathrm{Hg}$ at the gasifier outlet, $0.20-1.80 \mathrm{~mm} \mathrm{Hg}$ at the water scrubber outlet and $2.15-4.60 \mathrm{~mm} \mathrm{Hg}$ at the filter box outlet. It was found that they were small at the wet product gas flow rate of around $8.145 \mathrm{~N} \mathrm{~m}^{3} \mathrm{~h}^{-1}$. Experiment was carried out at $800^{\circ} \mathrm{C}$ for coconut shell, ground nut shell and rice husk. The producer gas analysed and the results were plotted in the graph. The percentage of composition of $\mathrm{H}_{2}, \mathrm{CO}, \mathrm{CH}_{4}, \mathrm{CO}_{2}$, and $\mathrm{N}_{2}$ are shown in Fig.3. The calorific values of the producer gas for these three materials were founded out (Table 1).

\section{Conclusion}

Combustible gases can be produced from coconut shell, ground nut shell and rice husk; they were utilized as a feedstock in a down draft gasifier. The calorific value of the coconut shell is more than groundnut shell and rice husk. The coconut shell has more carbon content and producer gas.

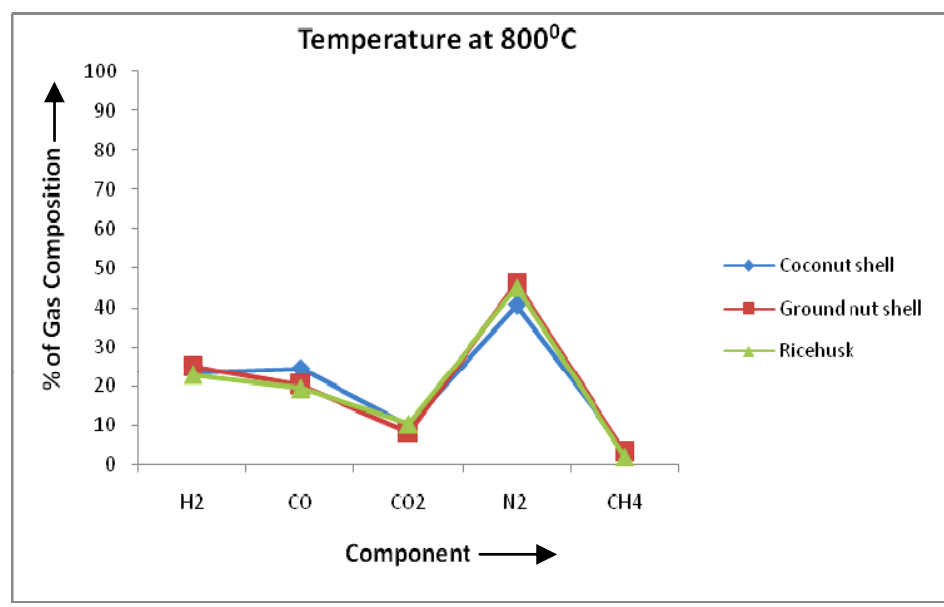

Fig.3. Gas composition of various biomass materials

Table 1. Calorific value of various biomass materials

\begin{tabular}{|l|c|}
\hline Shell Materials & Calorific value Kcal/Kg \\
\hline Coconut Shell & 5500 \\
\hline Groundnut Shell & 4229 \\
\hline Rice Husk & 3000 \\
\hline
\end{tabular}

The hydrogen amount in the producer gas for ground nut shell is more than coconut shell and rice husk. But carbon monoxide is $17.55 \%$ and $21.22 \%$ higher than ground nut shell and Rice husk in Coconut shell.. Also $6.15 \%$ and $38.71 \%$ methane are highly present in coconut shell than the other two shells. The coconut shell have more carbon content and also in producer gas.

Coconut shell is one of the waste biomass and easily available material. It is the best alternative energy source shell material.

\section{References}

1. Adnan Midilli, Murat Dogru, Colin R, Howarth Mike, Ling $\mathrm{J}$ and Teoman Ayhan (2001) Combustible gas production from sewage sludge with a down draft gasifier. Energy Conservation \& Management, 42,157-172.

2. Avdhesh $K$ and Sharma R (2009) Experimental study on $75 \mathrm{KW}$ the downdraft (biomass) gasifier system. Renewable Energy. 34, 1726-1733.

3. Dogru M, Howarth CR, Akay G, Keskinler B and Malik AA (2002) Gasification of hazelnut shells in a down draft gasifier. Energy. 27, 415-427.

4. Khater EMH, El-Ibiary NN, Khattab IA and Hamad MA (1992) Gasification of rice hulls. Biomass \& Bioenergy. 3, 329-333.

5. Pattarporn Chairprasert and Tharapong Vitidsant (2009) Promotion of coconut shell gasification by steam reforming on nickle-dolomite. Am. J. Appl. Sci. 6(2), 332-336.

6. Paulo R. Wander and Carlos R (2004) Assessment of a small saw dust gasification unit. Bio mass \& Bio Energy. 27, 467-476.

7. Philippe Mathew and Raphael Dubuisson (2002) Performance analysis of a biomass gasfier. Energy Conversion \& Management. 43, 1291-1299.

8. Savitri Garivait and Ulonwan Chaiyo (2006) Physical and chemical properties of Thai biomass fuels from agricultural residues. $2^{\text {nd }}$ Intl. Conf. on Sustainable Energy \& Environment.

9. Singh RN, Jena U, Patel JB and Sharma AM (2006) Feasibility study of cashew nut shells as an open core gasifier feedstock. Renewable Energy. 31,481487.

10. Van der Drift A, Van Doorm J and Vermeulen JW (2001) Ten residual biomass fuels circulating fluidized-bed gasification. Biomass \& Bio-energy. 20, 45-56. 